\title{
Growth and metabolic responses of the giant clam - zooxanthellae symbiosis in a reef-fertilisation experiment
}

\author{
C. A. Belda-Baillie ${ }^{1,2, *}$, W. Leggat ${ }^{1}$, D. Yellowlees ${ }^{1, * *}$ \\ ${ }^{1}$ Department of Biochemistry and Molecular Biology and ${ }^{2}$ Department of Zoology, James Cook University of \\ North Queensland, Townsville, Queensland 4811, Australia
}

\begin{abstract}
To evaluate the impact of elevated nutrients on reef organisms symbiotic with zooxanthellae, giant clams Tridacna maxima were exposed daily to increased ammonia and phosphate (N, $\mathrm{P}$, $\mathrm{N}+\mathrm{P}$ ) in their natural reef environment for 3 to $6 \mathrm{mo}$. The results strongly corroborate the major responses of the symbiotic association to nutrient enrichment previously observed (with $T$. gigas) under controlled outdoor conditions. Exposure of the clams to elevated $\mathrm{N}(10 \mu \mathrm{M})$ increased zooxanthellae density, reduced zooxanthellae size, down-regulated $\mathrm{N}$ uptake by zooxanthellae freshly isolated from their hosts, and reduced glutamate in the clam haemolymph, with increased pools of some free amino acids (methionine, tyrosine) in the zooxanthellae. These results confirm that the zooxanthellae in giant clams are $\mathrm{N}$ limited in situ and have free access to inorganic $\mathrm{N}$ from the sea water. There is also corroborating evidence that the zooxanthellae are $\mathrm{P}$ limited in situ as well, possibly due to host interference. While the N:P ratios of the animal host reflected ambient $N$ and $P$ concentrations in the sea water, those of the zooxanthellae did not. Regardless of $P$ exposure $(2 \mu \mathrm{M}$ P) of the clams, zooxanthellae $N: P$ ratios were consistently high $(>30: 1)$ and phosphate concentrations in the clam haemolymph bathing the zooxanthellae tube system consistently low $(<0.1 \mu \mathrm{M})$. These field findings, consistent with previous laboratory observations, confirm the limiting roles of both $\mathrm{N}$ and $\mathrm{P}$ in the giant clam-zooxanthellae symbiosis. That significant changes occurred earlier and at lower nutrient loading compared to some reef organisms investigated within the same experimental framework further demonstrates organismlevel responses of a potential bio-indicator of the early onset of eutrophication in reef waters.
\end{abstract}

KEY WORDS: Giant clam - Zooxanthellae - Symbiosis Nutrient limitation - Bio-indicators - Eutrophication

\section{INTRODUCTION}

Like many marine invertebrates symbiotic with photosynthetic dinoflagellates (Symbiodinium sp.) called zooxanthellae, tridacnid clams are able to thrive in the nutrient-poor tropical waters of the Indo-Pacific region The tridacnids' efficient utilisation of particulate organic matter through filter-feeding (Klumpp et al. 1992), and the algal symbionts' capability to recycle scarce nutrients are characteristics that are advantageous in oligotrophic

- Present address: Manne Science Institute, University of the Philippines, Diliman, Quezon City 1101, The Philippines

- Addressee for correspondence.

E-mail: david.yellowlees@jcu.edu.au tropical waters (Hawkins \& Klumpp 1995). Adapted to such an impoverished environment, the giant clams' growth and physiology can be strongly influenced by elevated nutrient concentrations from natural or anthropogenic events. For instance, it has previously been demonstrated that a major effect of chronically elevated nutrients (mainly $\mathrm{N}$ ) on giant clams is enhancement of soft-tissue production (Hastie et al. 1992, Belda et al. 1993b, Fitt et al. 1993), with a simultaneous weakening of the shell structure ( 5 to $10 \mu \mathrm{M} \mathrm{N}, 2$ to $10 \mu \mathrm{M} \mathrm{P}$ ) (Belda et al. 1993a). While the former effect is appealing to onshore ventures in the commercial mariculture of these bivalves, the effect on calcification has adverse implications for calcifying organisms in reef waters with elevated nutrient concentrations. 
It is notable that such gross changes in clam tissue production with $\mathrm{N}$-enrichment are accompanied by more subtle effects on a range of metabolic parameters including: $\mathrm{C}: \mathrm{N}: \mathrm{P}$ ratios of the animal tissue; ammonia/ammonium concentration in the clam haemolymph (Fitt et al. 1995); and density, chlorophyll a content, and ammonium uptake rates of the zooxanthellae (Belda et al. 1993b). While these responses to elevated nutrients (along with a lack of change in other properties) provide useful information on the metabolic relationship between the clam and its algal symbionts, they are also indicative of the nutrient regimen in which the symbiotic partners are growing. As such these parameters may represent powerful environmental tools for evaluating current and perhaps recent nutrient exposure of reef organisms. Identification of bio-indicators of the early onset of eutrophication on coral reefs should prove extremely useful.

Studies elucidating the effects of inorganic nutrients on coral reef organisms have been few until recently. One of the first collaborative programs to address the issue of nutrient effects on reef-building corals was the 1991 US-Israel workshop at the Hawail Institute of Marine Biology in Kaneohe Bay, Hawaii, USA (Jokiel et al. 1994). Exposure of 2 species of Hawaiian corals, Pocillopora damicornis and Montipora verrucosa, in tanks containing elevated $\mathrm{N}(20$ and $50 \mu \mathrm{M}$ as $\left.\left(\mathrm{NH}_{4}\right)_{2} \mathrm{SO}_{4}\right)$ significantly affected a broad spectrum of growth and metabolic parameters of the symbiotic partners. $\mathrm{N}$ enrichment increased areal concentrations of zooxanthellae and chlorophyll, host protein and zooxanthellae $N$, but did not affect host $C: N: P$ ratio (Muller-Parker et al. 1994a, b); increased zooxanthellae mitotic index and growth rate, and disrupted the cell division phase (Hoegh-Guldberg 1994); decreased glutamine synthetase (GS) activity of the host as well as the GS activity and ammonium uptake capacity of freshly isolated zooxanthellae (Yellowlees et al. 1994); and increased gln:glu (glutamine:glutamic acid) and pool sizes of most free amino acids in the zooxanthellae (McAuley 1994).

It should be noted that the above studies were conducted under carefully controlled conditions in an artificial environment and in the absence of other major organisms. They do not guarantee that parallel studies in situ would yield similar results. Although such laboratory studies are quite useful and necessary in isolating the effects of a complex range of environmental factors on reef organisms, they are necessarily limited by the handling sensitivity of the experimental organisms and the inadequate simulation of conditions in the field, which is usually an extremely complex and heterogeneous environment. The presence of other organisms competing for available nutrients, for instance, could conceivably decrease the clam's re- sponses in situ or confound the effects of nutrients. In the case of sewage outfall in Kaneohe Bay (Kinsey 1988), there was a pronounced shift in community structure. The resulting enhancement of phytoplankton growth favoured the dominance of particle feeders, loss of available substratum, reduction in light penetration, and decline in benthic primary production. In an early experiment of Kinsey \& Domm (1974), however, where nitrogen (mainly urea) and phosphorus were added daily to a patch reef over $8 \mathrm{mo}$, a striking $50 \%$ reduction in calcification of the reef system was evident (Kinsey \& Davies 1979), along with a $25 \%$ enhancement in primary productivity due to increased benthic algae. Clearly, experimental manipulations in the field are necessary to better understand the impact of eutrophication on reef organisms.

The Enrichment of Nutrients on a Coral Reef Experiment or ENCORE is the latest initiative and the first fully replicated and controlled field experiment on the long-term effect of elevated nutrients on reef communities. This large-scale manipulative reef-fertilisation experiment was carried out on Australia's Great Barrier Reef (GBR) by the Great Barrier Reef Marine Park Authority from 1993 to 1996 in response to a global concern about the effect of eutrophication on coral reefs. This interdisciplinary undertaking, consisting of acclimation, nutrient enrichment, and recovery phases, was designed to: (1) provide quantitative evidence on the relative impacts of elevated $N$ and $P$ on various reef organisms, and the processes that regulate these responses; and (2) test the usefulness of parameters proposed as sub-lethal indicators of eutrophication (Larkum \& Steven 1994). The present study on giant clams was part of this initiative.

In this paper, the results of an in situ experiment on a natural population of Tridacna maxima are presented. The major aim of this study was to test if clams ( $T$ maxima) periodically exposed to increased nutrients in their natural environment would behave in a manner similar to clams ( $T$. gigas) similarly investigated in an essentially artificial environment (Belda et al. 1993a, b; Belda \& Yellowlees 1995). Indeed, the present field findings are, in most cases, consistent with previous laboratory observations, and together constitute valuable information that is useful in reaching definitive conclusions regarding the impact of nutrient enrichment on reef organisms such as giant clams and their zooxanthellae.

\section{MATERIALS AND METHODS}

Experimental design and maintenance. This study constituted a part of ENCORE, a large-scale, manipulative reef-fertilisation experiment undertaken on the 
GBR to document the responses of coral reefs to nutrient enrichment. This multi-agency project was conducted at the relatively pristine One Tree Island Reef $\left(23^{\circ} 30^{\prime} \mathrm{S}, 152^{\circ} 06^{\prime} \mathrm{E}\right.$ ) in the Mackay/Capricorn Section of the GBR Marine Park. The experimental design used here has already been described in detail by Larkum \& Steven (1994).

In total, 96 indigenous Tridacna maxima, ranging from 15 to $30 \mathrm{~cm}$ in shell length, were collected from the eastern crest of One Tree Island reef and randomly allocated to 12 patch reefs or micro-atolls of similar size ( 16 to $25 \mathrm{~m}$ across), volume ( 46 to $152 \mathrm{~m}^{3}$ ), and benthic composition. These micro-atolls were, in turn, randomly allocated to 1 of 4 nutrient treatments, namely, nitrogen $(\mathrm{N})$, phosphorus $(\mathrm{P}), \mathrm{N}+\mathrm{P}$, or no nutrient (control), such that there were 3 micro-atolls per treatment. The clams were acclimated on the micro-atolls for about 7 mo during the pre-nutrient enrichment phase of the ENCORE experiment (February to August 1993). Using computer-controlled nutrient-dispersal units, $\mathrm{NH}_{4} \mathrm{Cl}$ and/or $\mathrm{KH}_{2} \mathrm{PO}_{4}$ were simultaneously added to 9 micro-atolls to achieve, at the time of addition, concentrations of $10 \mu \mathrm{MN}$ and/or $2 \mu \mathrm{MP}$, respectively. Fertilisation occurred once at each low tide, when the water contained within the micro-atolls was isolated from the surrounding lagoon for about 4 to $5 \mathrm{~h}$. Despite ponding of the micro-atolls, nutrient concentrations were detectable above background levels $(0.8$ to 1.8 $\mu \mathrm{M} \mathrm{N}, 0.18$ to $0.30 \mu \mathrm{MP}$ ) for only 2 to $3 \mathrm{~h}$ after addition. The micro-atolls were therefore exposed to a pulse of nutrients rather than a fixed concentration for the duration of ponding. This initial nutrient enrichment phase ran from September 1993 to December 1994.

A second nutrient enrichment phase consisting of more frequent (thrice every low tide) and higher nutrient loading ( $20 \mu \mathrm{M} \mathrm{N}, 4 \mu \mathrm{M}$ P) was carried out from January to December 1995. Nevertheless, the present study on giant clams was confined to the second phase of ENCORE, when nutrients were added only once every low tide.

Measurement of clam biomass. Two clams were collected from each micro-atoll after 1 and then 3 mo of fertilisation. Before removal of the clams from the micro-atolls, a wooden wedge was inserted between the gaping valves in order to keep the valves open for later extraction of the soft tissues from the shell. Once in the laboratory, each clam was immediately inverted onto a beaker to drain any sea water trapped inside its mantle cavities. Using a scalpel, the soft-tissue mass was extracted from the shell by cutting the mantle and adductor muscles away from the inner surface of both valves, being careful not to rupture any visceral organs in the process.

Shell length (longest axis) was measured to the nearest mm using calipers. After removing the clam from its shell, the mantle was excised from the rest of the soft tissues. Residual sea water and haemolymph were blotted from the soft tissues with paper towels. The tissues were weighed separately to the nearest $0.01 \mathrm{~g}$. Whole-clam, viscera, and mantle tissues were freeze dried and analysed for $\mathrm{C}$ and $\mathrm{N}$ composition using a CHN analyser (LECO CHN-600, Australian Institute of Marine Science, Townsville; CARLO ERBA EA-1108CHN, James Cook University), and for $\mathrm{N}$ and $\mathrm{P}$ composition using the hydrogen peroxide-sulfuric acid digestion technique of Allen (1974).

Measurement of nutrient levels in clam haemolymph. During extraction of the soft tissues from the shell, the haemolymph was collected in a beaker and the volume recorded. The haemolymph was centrifuged at $2000 \times \mathrm{g}$ for $10 \mathrm{~min}$ to remove cells and debris. Haemolymph $(30 \mathrm{ml})$ was immediately analysed for ammonia using a modification (Wilkerson \& Trench 1986) of the method of Liddicoat et al. (1975). After adding the appropriate reagents, the samples were centrifuged at $1000 \times g(10 \mathrm{~min})$ to remove insoluble material before measuring the absorbance in a spectrophotometer. The rest of the haemolymph was stored frozen $\left(-20^{\circ} \mathrm{C}\right)$ prior to phosphate and phosphorus determinations. The frozen haemolymph was later thawed and mixed with $10 \%(\mathrm{w} / \mathrm{v})$ trichloroacetic acid to precipitate protein (see Deane \& O'Brien 1980). This was removed by centrifugation at $2000 \times g(10 \mathrm{~min})$ and the supernatant analysed for phosphate (Strickland \& Parsons 1972) and total phosphorus (Koroleff 1983). All assays were done in triplicate for each clam.

Measurement of zooxanthellae biomass. The mantle was cut into small pieces and homogenised in $0.45-\mu \mathrm{m}$-filtered sea water (FSW), the resulting homogenate centrifuged at $1000 \times g$ for $2.5 \mathrm{~min}$, before decanting the animal tissue. The algal pellet was then resuspended in FSW and the animal tissue removed by filtration through a double layer of clinical gauze cloth. Most of the remaining zooxanthellae from the animal tissue were washed through the filter with FSW. The total zooxanthellae filtrate was then centrifuged at $2000 \times g$ for $2.5 \mathrm{~min}$, the supernatant discarded, and the resulting algal pellet resuspended in FSW. The zooxanthellae were washed twice more or until the supernatant was clear, before finally resuspending the algal pellet in $20 \mathrm{ml}$ of FSW.

A known volume $(0.25 \mathrm{ml})$ of the final zooxanthellae suspension was preserved in buffered $10 \%$ formalin solution. Zooxanthellae density and size were determined under a compound microscope for 6 replicate subsamples from each algal suspension using a haemocytometer. A known volume (10 ml) of the final zooxanthellae suspension was also centrifuged at $1000 \times g$ for $2.5 \mathrm{~min}$ and the algal pellet stored at $-20^{\circ} \mathrm{C}$. The frozen pellets were later lyophilised over 
$24 \mathrm{~h}$ and weighed to the nearest $0.1 \mathrm{mg}$. The samples were then stored with silica gel at $-20^{\circ} \mathrm{C}$ until analysed for $C$ and $N$ composition.

Measurement of $\mathbf{N}$ uptake by freshly isolated zooxanthellae. Prior to nutrient-uptake experiments, freshly isolated zooxanthellae (FIZ) were maintained in the dark by wrapping them in aluminium foil. The density of the FIZ suspension was estimated and, if necessary, an appropriate dilution was made to obtain a density of ca $10^{8}$ cells $\mathrm{ml}^{-1}$. Solutions $(20 \mathrm{ml})$ of $20 \mu \mathrm{M}$ ammonium $(\mathrm{N})$ in FSW were prepared in triplicate in small glass scintillation vials. To obtain a final density of ca $10^{6}$ cells $\mathrm{ml}^{-1}$ in the incubation vials, $0.2 \mathrm{ml}$ of the FIZ suspension was added to each of the triplicate vials at $15 \mathrm{~s}$ intervals. Triplicate vials without FIZ were kept as controls for the determination of bacterial $N$ uptake in FSW. The FIZ were then incubated in ammonium solution for 30 to $60 \mathrm{~min}$ in the light (50 to $200 \mu \mathrm{E} \mathrm{m} \mathrm{m}^{-2}$ $\mathrm{s}^{-1} ; 26$ to $28^{\circ} \mathrm{C}$ ). After incubation, the FIZ were successively filtered on GF/C glass-fibre filters at $15 \mathrm{~s}$ intervals and the filtrates were immediately analysed for ammonia.

Measurement of amino-acid contents of the clam haemolymph and zooxanthellae. For amino-acid analysis, 3 other clams were removed from each of the micro-atolls after approximately $6 \mathrm{mo}$ in the different nutrient regimens. These clams were killed and the haemolymph collected and frozen as previously described. Zooxanthellae were extracted from the mantle, pelleted at $1200 \times g$ for $2 \mathrm{~min}$, and frozen.

The total amino-acid concentration (excluding proline) in the haemolymph was determined for each clam using a modification of the method described by Magne \& Larher (1992). Haemolymph samples were thawed and centrifuged at $1600 \times g$ for $10 \mathrm{~min}$. To $100 \mu \mathrm{l}$ of haemolymph, $1.4 \mathrm{ml}$ of sodium citrate $(\mathrm{pH} 4.5)$ and $1 \mathrm{ml}$ of a ninhydrin/ascorbic acid solution (1\% ninhydrin, $0.03 \%$ ascorbic acid dissolved in ethylene glycol monomethyl ether) were added. The solution was shaken and placed in a boiling water bath for $15 \mathrm{~min}$ before being cooled to room temperature. After addition of $3 \mathrm{ml}$ of $60 \%$ ethanol, the absorbance was measured at $570 \mathrm{~nm}$ and the total amino-acid concentration was calculated using glycine as a standard.

Haemolymph samples from control and $\mathrm{N}$-supplemented clams were also analysed for individual amino acids. The haemolymph was thawed, centrifuged for 5 min at $800 \times g$ and diluted between 100 - and 300 -fold using $\mathrm{dH}_{2} \mathrm{O}$. The amino acids were derivatised by addition of $10 \mu \mathrm{l}$ o-pthaldialdehyde (Pierce) $\left(5 \mathrm{mg} \mathrm{ml}^{-1}\right.$ in $0.5 \mathrm{M}$ potassium borate $\mathrm{pH} 10$ and $4 \mu \mathrm{l} \mathrm{ml^{-1 }} 2$-mercaptoethanol) to $100 \mu$ of each sample immediately prior to analysis. Samples were then diluted with a solution of $18.2 \%$ acetonitrile, $18.2 \%$ 2-mercaptoethanol, $18.2 \%$ isopropyl alcohol, and $45.4 \%$ of
$0.06 \mathrm{M} \mathrm{KH}_{2} \mathrm{PO}_{4} / 0.06 \mathrm{M} \mathrm{K}_{2} \mathrm{HPO}_{4}(\mathrm{pH}$ 6.65), so that the final total amino-acid concentration was between 15 and $45 \mu \mathrm{M}$. From each sample, $10 \mu \mathrm{l}$ of sample was separated on a Waters NOVA-PAK ${ }^{T+1} \mathrm{C}_{18}$ column with a mobile phase described by the manufacturers (Waters) as gradient 2. Amino-acid derivatives were detected with a fluorescence detector (Waters model $420 \mathrm{AC}$ ). The software Maxima 820 (Millipore) was used to determine individual peak areas and concentrations. It was not possible to separate serine and histidine so data from these amino acids were pooled for analysis.

Zooxanthellae samples were thawed and resuspended in FSW. Cell counts were made using a haemocytometer. The zooxanthellae were lysed by resuspension in $80 \%$ ethanol, centrifuged at $15000 \times g$ for $5 \mathrm{~min}$, and the supernatant analysed for amino acids by high-performance liquid chromatography (McAuley 1994).

Analysis of data. To test the hypothesis that elevated levels of $\mathrm{N}$ and $\mathrm{P}$ had no effect on the various clam and zooxanthellae parameters at $\alpha=0.05$, data were analysed using analysis of variance (ANOVA) for 2 orthogonally arranged fixed factors ( $N$ and $P$ ), with a third random factor (micro-atoll) nested within each treatment combination (Underwood 1981). All statistical analyses were performed using the analytical software package, Statistix 3.0 (Analytical Software 1985). Cochran's test for the assumption of homoscedasticity of variances underlying the analytical procedure was made prior to performing each analysis (Underwood 1981). Except for the FIZ $N$ uptake and some aminoacid data (Cochran's test, $\mathrm{p}<0.05$ ), no serious violations of the assumptions were evident in the different data sets (Cochran's test, $p>0.05$ ). Data for $N$ uptake by FIZ and some amino acids in zooxanthellae were log-transformed to conform to the assumption of homogeneity of variances (Cochran's test, $\mathrm{p}>0.05$ ). Where observed $F$ ratios were less than unity, significance tests at $\alpha=0.05$ based on the reciprocal of the observed $F$ ratios were performed (Underwood 1981). In all cases, $F$ ratios were not improbably small $(p>0.05)$, which implies that the assumptions of the analysis were not seriously violated (Underwood 1981). Where the ANOVA results were significant, Tukey's test was used to compare treatment means (Zar 1984).

\section{RESULTS}

Significant differences between control and $\mathrm{N}$ enriched clams were obtained within 3 mo of fertilisation of the clams. Observed trends in the symbiotic partners' N:P ratios and the host haemolymph's nutrient levels after a month of fertilisation were consistent with trends after 3 mo. 


\section{$\mathrm{N}: \mathrm{P}$ ratios in clam viscera and zooxanthellae}

After 3 mo of fertilisation, addition of $\mathrm{P}$ alone significantly decreased the N:P ratio in the soft tissues of Tridacna maxima (ANOVA: $F=6.57$, df $=1.8, \mathrm{p}<0.05$ ), indicating increased phosphorus content (Tukey, $\mathrm{p}<$ 0.05) (Fig. 1). Addition of $\mathrm{N}$ alone, on the other hand, significantly increased the N:P ratio (ANOVA: $F=8.13$, $\mathrm{df}=1,8, \mathrm{p}<0.05)$, indicating increased nitrogen content (Tukey, $\mathrm{p}<0.05$ ). Addition of $\mathrm{N}+\mathrm{P}$ did not appear to affect the $\mathrm{N}$ :P ratio of $T$. maxima, with no significant interaction between $\mathrm{N}$ and $\mathrm{P}$ (ANOVA: $F=1.00, \mathrm{df}=$ $1,8, \mathrm{p}>0.05$ ). It is assumed that increased $\mathrm{N}$ and $\mathrm{P}$ simultaneously increased nitrogen and phosphorus content, resulting in a constant $\mathrm{N}: \mathrm{P}$ ratio. There was no significant variation in $\mathrm{N}: \mathrm{P}$ ratios due to the different micro-atolls (ANOVA: $F=0.85$, df $=8,12, p>0.05$ ). Most of the viscera samples taken after only 1 mo of fertilisation were lost due to a malfunction of storage equipment. Only 4 samples were saved and analysed giving the following N:P ratios: (1) Control $=28: 1$, (2) N $=36 \pm 2: 1$, and (3) $\mathrm{P}=24: 1$. The observed trend, though based on single readings, was similar to the trend after 3 mo of fertilisation.

In contrast to the animal tissue, the N:P ratios of the zooxanthellae after 3 mo of fertilisation were similar in all treatments (ANOVA: for $\mathrm{N}$ effect, $F=0.01, \mathrm{df}=1,8$, $p>0.05$; for P effect, $F=0.49$, df $=1,8, p>0.05$ ), with a mean $( \pm \mathrm{SE})$ value of $34.2 \pm 0.9$ across all treatments (Table 1). There was no significant interaction between $\mathrm{N}$ and $\mathrm{P}$ (ANOVA: $F=1.36, \mathrm{df}=1,8, \mathrm{p}>0.05$ ) and no variation due to the different micro-atolls (ANOVA: $F=$ 2.19, $\mathrm{df}=8,12, \mathrm{p}>0.05)$ A similar trend was observed a month after fertilisation (Table 1).

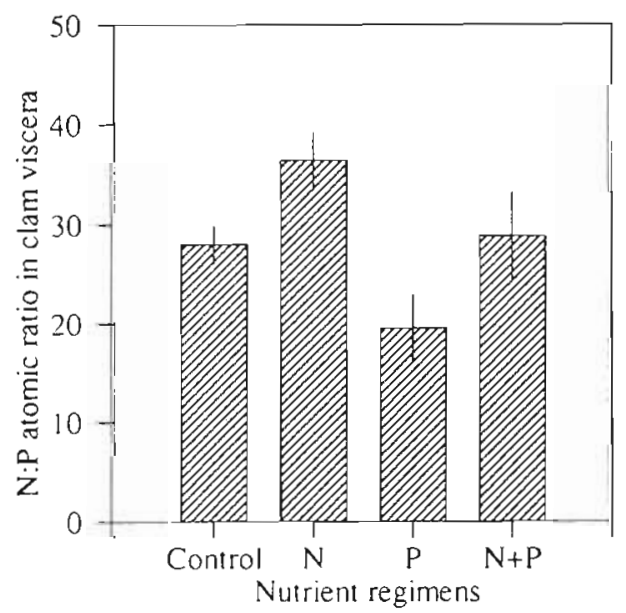

Fig. 1. Tridacna maxima. Mean N:P atomic ratios of the visceral tissues of giant clams in controls or supplemented for 3 mo with ammonium $(10 \mu \mathrm{MN})$ and/or phosphate $(2 \mu \mathrm{MP})$ on micro-atolls on One Tree Island Reef, Great Barrier Reef, Australia (error bars: $\pm S E, n=6$ )
Table 1. Mean ( \pm SE) N:P atomic ratios of zooxanthellae isolated from Tridacna maxima in controls or supplemented with ammonium $(\mathrm{N})$ and phosphate $(\mathrm{P})$ on micro-atolls on One Tree Island Reef

\begin{tabular}{|lcrcr|}
\cline { 2 - 5 } Treatment & $1 \mathrm{mo}$ & $(\mathrm{n})$ & $3 \mathrm{mo}$ & $(\mathrm{n})$ \\
\hline Control & $48.7 \pm 7.8$ & $(6)$ & $33.1 \pm 2.0$ & $(6)$ \\
$\mathrm{N}$ & $45.9 \pm 3.0$ & $(6)$ & $38.0 \pm 3.8$ & $(4)$ \\
$\mathrm{P}$ & $48.0 \pm 3.4$ & $(6)$ & $33.0 \pm 0.6$ & $(6)$ \\
$\mathrm{N}+\mathrm{P}$ & $44.3 \pm 3.0$ & $(6)$ & $34.0 \pm 2.2$ & $(6)$ \\
Mean & $46.7 \pm 2.2$ & $(24)$ & $34.2 \pm 0.9$ & $(22)$ \\
\hline
\end{tabular}

\section{N uptake by FIZ}

After 3 mo of fertilisation, FIZ from N-treated clams took up significantly less ammonium (ANOVA: $F=$ 10.46, $\mathrm{df}=1,8, \mathrm{p}<0.05$ ), and FIZ from P-treated clams took up significantly more ammonium (ANOVA: $F=$ 6.99 , df $=1,8, p<0.05)$, than those from control clams (Tukey, p<0.05) (Fig. 2). FIZ from N+P- treated clams had $N$-uptake rates similar to those from control clams (Tukey: $p>0.05$ ). There was no significant interaction between $\mathrm{N}$ and P (ANOVA: $F=0.01, \mathrm{df}=1,8, \mathrm{p}>0.05$ ), nor was there variation due to the different microatolls (ANOVA: $F=1.39, \mathrm{df}=8,11, \mathrm{p}>0.05$ ). A similar trend was evident after only 1 mo but was not significant (ANOVA, $p>0.05$ ).

\section{Zooxanthellae density and size}

After 3 mo of fertilisation, zooxanthellae densities in the $\mathrm{N}$ - and $\mathrm{N}+\mathrm{P}$-treated clams were higher than those

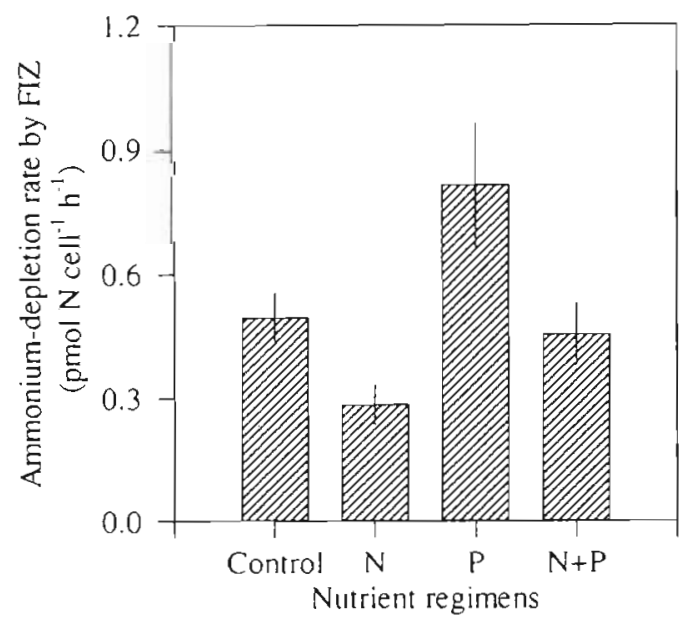

Fig. 2. Symbiodinium sp. Mean ammonium-uptake rates of freshly isolated zooxanthellae (FIZ) from Tridacna maxima in controls or supplemented for 3 mo with ammonium (10 $\mu \mathrm{MN})$ and phosphate $(2 \mu \mathrm{M} P)$ on micro-atolls on One Tree Island Reef (error bars: \pm SE, $n=6$ ) 

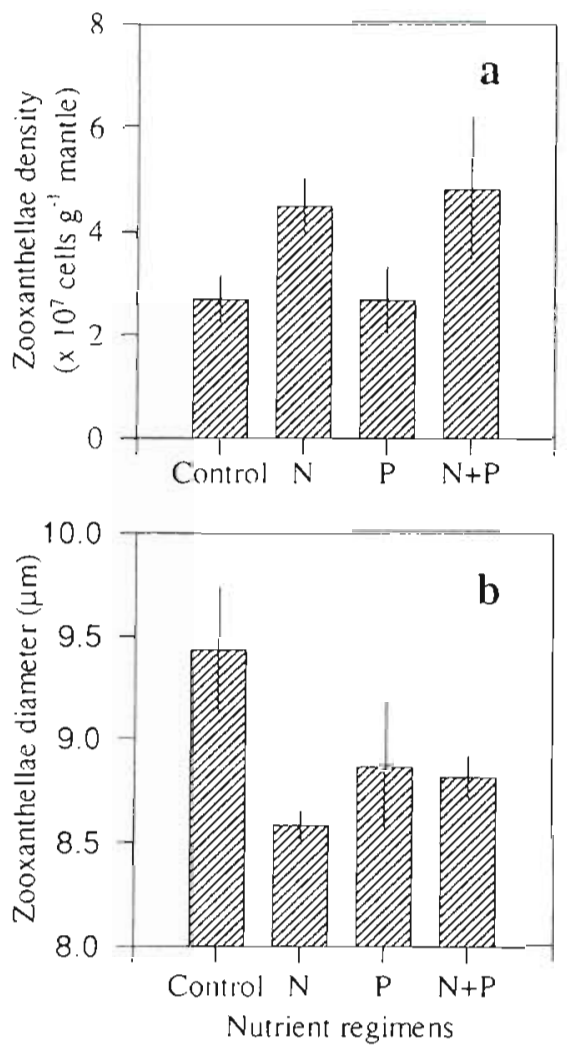

Fig. 3. Symbiodinium sp. (a) Mean density and (b) mean diameter of zooxanthellae from Tridacna maxima in controls or supplemented with ammonium $(10 \mu \mathrm{M} \mathrm{N})$ and/or phosphate $(2 \mu \mathrm{M} P)$ for 3 mo on micro-atolls on One Tree Island Reef (error bars: $\pm \mathrm{SE}_{1} \mathrm{n}=6$ )

in the control and P-treated clams (Fig. 3a). These differences, however, were not statistically significant (ANOVA: for $\mathrm{N}$ effect, $F=2.77, \mathrm{df}=1,8, \mathrm{p}>0.05$; for $\mathrm{P}$ effect, $F=0.02, \mathrm{df}=1,8, p>0.05$ ). The statistical significance of the effects due to the treatments was potentially obscured by the highly significant variation found due to the different micro-atolls (ANOVA: $F=$ $7.91, \mathrm{df}=8.12, \mathrm{p}<0.001)$. There was no significant interaction between $\mathrm{N}$ and $\mathrm{P}$ (ANOVA: $F=$ $0.02, \mathrm{df}=1,8, \mathrm{p}>0.05)$. Zooxanthellae densities after a month of fertilisation showed no trend and were not significantly different between treatments (ANOVA: $\mathrm{p}>0.05$ ).

Similarly, addition of $N$ and $N+P$, but not $P$, significantly decreased the mean diameter of the zooxanthellae (ANOVA: for $\mathrm{N}$ effect, $F=$ 4.28, df $=1,20, \mathrm{p}<0.05$; for $\mathrm{P}$ effect, $F=0.59$, $\mathrm{df}=1,20, p>0.05$ ) (Fig. 3b). This significant effect of $\mathrm{N}$ on zooxanthellae size was detected after removing the micro-atoll factor as a source of variation from the analysis in view of its non-significant effect (ANOVA: $F=0.99, \mathrm{df}=8.12, p=0.49$ ), and subsequent pooling of the micro-atoll and residual mean squares for testing of $\mathrm{N}$ effect (Underwood 1981). The microatoll factor had been safely assumed to be zero since it was not detected by an $F$ ratio at $p=0.25$ (instead of the usual $p=0.05$ ), a test powerful enough to guard against a Type II error. There was no significant interaction between $\mathrm{N}$ and $\mathrm{P}$ (ANOVA: $F=3.41, \mathrm{df}=1,20$, $p>0.05$ ). No significant differences in zooxanthellae size were discernible after a month of fertilisation (ANOVA, $p>0.05$ ).

\section{Ammonia, phosphate, and total phosphorus levels in haemolymph}

After 3 mo of exposure to nutrients, there were no significant differences in the levels of phosphate, total phosphorus, and ammonia in the haemolymph (ANOVA: $\mathrm{p}>0.05$ ) in all treatments (Table 2). For ammonia in the haemolymph, there was a significant variation due to the different micro-atolls (ANOVA: $F=$ 3.34 , $\mathrm{df}=8.12, p<0.05$ ). Ammonia levels were surprisingly high, while phosphate concentrations were very low $(<0.1 \mu \mathrm{M})$, similar to trends observed only a month after fertilisation (Table 2). After 3 mo of fertilisation, ammonia levels were reduced to about $50 \%$ of the levels observed after a month of fertilisation (Table 2).

\section{Amino-acid contents of the clam haemolymph and zooxanthellae}

After 6 mo of fertilisation, increased $\mathrm{N}$ significantly reduced glutamate (glu) in the clam haemolymph (ANOVA: $F=11.33, \mathrm{df}=1,4, \mathrm{p}<0.05$ ) (Fig. 4 a), with no significant variation due to the different micro-atolls (ANOVA: $F=0.12, \mathrm{df}=4,12, \mathrm{p}>0.05$ ). Gin:Glu, however, and the rest of the amino acids (total, gln (glutamine), asp (asparatic acid), ser (serine), his (histidine), arg (arginine), gly (glycine), ala (alanine), tau (tau-

Table 2. Tridacna maxima. Mean $( \pm \mathrm{SE})$ concentrations $(\mu \mathrm{M})$ of inorganic phosphate $\left(\mathrm{P}_{1}\right)$, total phosphorus $\left(\mathrm{P}_{t}\right)$, and ammonia in the baemolymph of giant clams in controls or supplemented with ammonium (N) and phosphate (P) on micro-atolls on One Tree Island Reef $(n=6$, nd: no data due to technical problem)

\begin{tabular}{|lcccccc|}
\hline \multirow{3}{*}{ Treatment } & \multicolumn{3}{c}{1 mo } & & \multicolumn{3}{c|}{3 mo } \\
& $P_{1}$ & $P_{t}$ & Ammonia & $P_{1}$ & $P_{1}$ & Ammonia \\
\hline Control & $<0.1$ & $35.8 \pm 2.3$ & $43.5 \pm 4.2$ & $<0.1$ & nd & $22.4 \pm 3.2$ \\
$\mathrm{~N}$ & $<0.1$ & $37.3 \pm 4.7$ & $35.7 \pm 2.7$ & $<0.1$ & nd & $23.0 \pm 2.4$ \\
$\mathrm{P}$ & $<0.1$ & $34.9 \pm 3.1$ & $40.9 \pm 3.8$ & $<0.1$ & nd & $19.4 \pm 1.1$ \\
$\mathrm{~N}+\mathrm{P}$ & $<0.1$ & $32.8 \pm 2.6$ & $41.8 \pm 2.9$ & $<0.1$ & nd & $22.8 \pm 2.0$ \\
Mean & $<0.1$ & $35.2 \pm 1.6$ & $40.5 \pm 1.7$ & $<0.1$ & nd & $21.9 \pm 1.1$ \\
& & & & & & \\
\hline
\end{tabular}



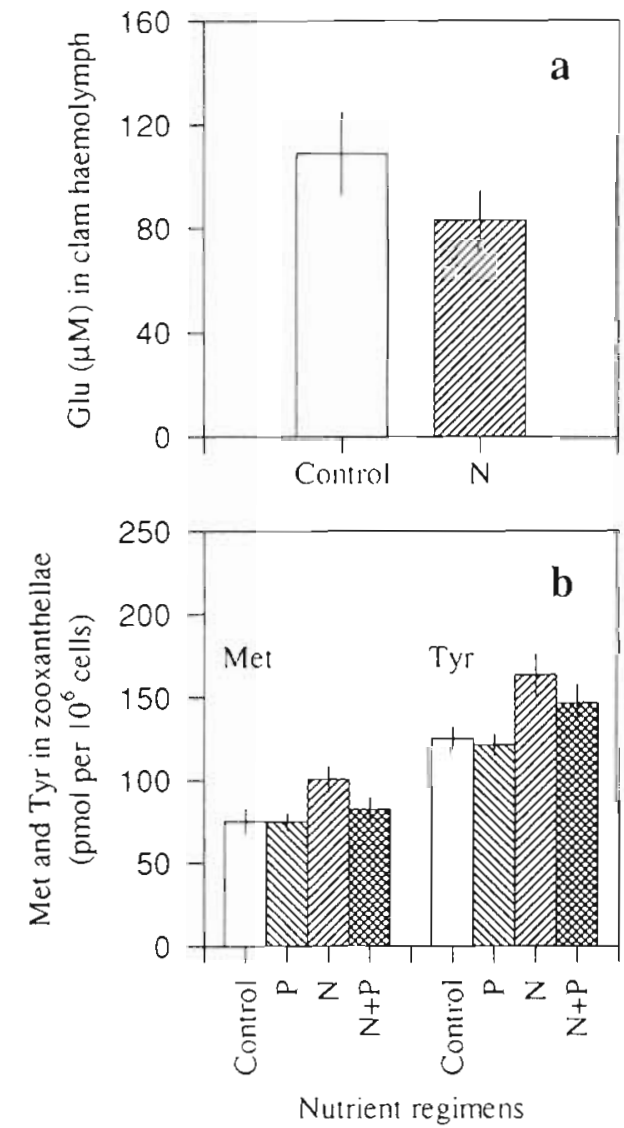

Fig. 4. Tridacna maxima and Symbiodinium sp. (a) Mean $( \pm \mathrm{SE}$ ) concentration of glutamate (glu) in the haemolymph (n = 9) of giant clams in controls or supplemented with ammonium (10 $\mu \mathrm{M} N)$ for $6 \mathrm{mo}$; (b) mean concentrations of methionine (met) and tyrosine (tyr) ( $n=9$ ) in the zooxanthellae of giant clams in controls or supplemented with ammonium. $(10 \mu \mathrm{M} \mathrm{N})$ and/or phosphate $(2 \mu \mathrm{M} \mathrm{P})$ for 6 mo on the microatolls on One Tree Island Reef.

rine)] were unaffected by $N$ (ANOVA: $p>0.05$ ), with no significant variation due to the different microatolls (ANOVA: $p>0.05$ ), except for glycine (ANOVA: $F=3.99, \mathrm{df}=4,12, \mathrm{p}<0.05)$.

Addition of $N$, but not $P$, significantly increased methionine in the zooxanthellae (ANOVA: for $\mathrm{N}$ effect, $F=6.24$, df $=1,8, \mathrm{p}<0.05$; for P effect, $F=1.96$, df $=$ $1,8, p>0.05$ ) (Fig. 5b). Similarly, addition of $N$, but not $P$, significantly increased tyrosine (tyr) in the zooxanthellae (ANOVA: for $N$ effect, $F=16.97$, df $=1,8, p<$ 0.05; for P effect, $F=1.82, \mathrm{df}=1,8, \mathrm{p}>0.05$ ) (Fig. $4 \mathrm{~b}$ ). For both met and tyr, there was no significant interaction between $N$ and $P$, nor was there a significant variation due to the different micro-atolls (ANOVA, $\mathrm{p}>$ $0.05)$. For most of the amino acids analysed from zooxanthellae [gln, glu, asp, asn (asparagine), gly, lys (lysine), orn (ornithine), phe (phenylanine), thr (threonine)], there was a significant variation due to the different micro-atolls (ANOVA, $\mathrm{p}<0.05$ ), potentially masking any effects of the nutrients on the amino-acid concentrations. Histidine (log-transformed) was neither affected by $N$ nor $P$ (ANOVA: $p>0.05$ ), with no significant interaction between $N$ and $P$, nor a significant variation due to the different micro-atolls (ANOVA, $\mathrm{p}>0.05$ ). The rest of the amino-acid data [total, gln:glu, ala, arg, ile (isoleucine), leu (leucine), ser, val (valine)] did not meet the assumptions of parametric analysis even after transformation (Cochran's test, $p>0.05$ ) and were not analysed further.

\section{DISCUSSION}

This study is one of the few reported field studies on the impact of nutrients on reef organisms which involves adequate replication and controls (Ambariyanto \& Hoegh-Guldberg 1996, Bishop \& Duckworth 1997. Hoegh-Guldberg et al. 1997, Kiene 1997. Larkum \& Koop 1997, Steven \& Broadbent 1997, Tentori et al. 1997. Ward \& Harrison 1997). Our in situ observations on Tridacna maxima strongly corroborate major responses previously observed for $T$. gigas under controlled outdoor conditions (Belda et al. 1993b, Belda \& Yellowlees 1995). Changes in ambient nutrient concentrations in sea water are generally reflected in a range of growth and metabolic parameters in both the animal host and the algal symbionts, with the exception that inorganic P generally has no effect on the resident zooxanthellae population. It is significant that the responses from $T$. maxima occurred as a result of a nutrient exposure that is not only periodic, but also at $\mathrm{N}$ and $\mathrm{P}$ concentrations significantly lower than those continuously supplied to $T$. gigas onshore over an equivalent period (Belda et al. 1993b). These results confirm our previous conclusions that zooxanthellae in giant clams are nutrient limited, and demonstrate the potential of the giant clam-zooxanthellae symbiosis as a bio-indicator of the early onset of eutrophication in coral reefs.

\section{Nutrient limitation in clam zooxanthellae}

The important limiting roles of both $\mathrm{N}$ and $\mathrm{P}$ in the growth and physiology of the symbiotic partners are evident. Increases in either $N$ or $P$ were directly reflected in the N:P ratios of the animal host, but not those of the zooxanthellae (Fig. 1, Table 1). The zooxanthellae's N:P ratios of $>30: 1$ strongly suggests that they are $\mathrm{P}$ limited in situ (see Atkinson \& Smith 1983, Belda \& Yellowlees 1995). Such P limitation is consistent with previous findings on freshly isolated zooxanthellae from P-enriched Tridacna gigas, which exhib- 
ited properties similar to those of zooxanthellae cultured in the absence of phosphate (Belda \& Yellowlees 1995). In the field, the density of symbiotic zooxanthellae increased with $\mathrm{N}$ - or $\mathrm{N}+\mathrm{P}$-enrichment, but not with P alone (Fig. 3a) (see also Belda et al. 1993b. Belda \& Yellowlees 1995, but cf. Steven \& Broadbent 1997). When cultured outside their clam host ( $T$. gigas), however, zooxanthellae readily responded to $P$ increases in sea water (Belda \& Yellowlees 1995). It is interesting that the inorganic phosphate concentration in clam haemolymph was found to be consistently low in $T$. maxima and $T$ gigas (i.e. $<0.1 \mu \mathrm{M}$ ) (Table 2) (Deane \& O'Brien 1980, Belda et al. 1993b). Such low concentrations of inorganic phosphate in the haemolymph surrounding the zooxanthellal tube system only further illustrates the poor $\mathrm{P}$ environment of zooxanthellae in situ, regardless of ambient $\mathrm{P}$ concentrations in the sea water (Belda et al. 1993b)

In addition to $P$ limitation, our data likewise suggest $\mathrm{N}$ limitation in the symbiotic zooxanthellae. For instance, zooxanthellae from the $\mathrm{N}$ - or $\mathrm{N}+\mathrm{P}$-treated clams had higher densities and were significantly smaller than zooxanthellae from the control or Ptreated clams (Fig. 3a, b). This is consistent with the reduced cross-sectional area observed for zooxanthellae isolated from a young batch of Tridacna maxima exposed to $\mathrm{N}$ or $\mathrm{N}+\mathrm{P}$ in a related ENCORE study (Ambariyanto \& Hoegh-Guldberg 1996). That fastdividing symbiotic zooxanthellae are usually smaller than slow-dividing ones can be attributed to the greater proportion of newly divided cells in the former than in the latter (Hoegh-Guldberg et al. 1986, Wilkerson et al. 1988, Ambariyanto \& Hoegh-Guldberg 1996), and the greater allocation of energy to reproduction than to growth (i.e. increase in size). It is also interesting that zooxanthellae from clams exposed to $\mathrm{N}$ had significantly lower $\mathrm{N}$-depletion rates than zooxanthellae from control clams (Fig. 2) (see also Belda et al. 1993b), similar to laboratory observations of zooxanthellae from corals (Yellowlees et al. 1994). This suggests that zooxanthellae from N-treated clams were exposed to increased ammonium in situ with increased $\mathrm{N}$ concentrations in sea water. In contrast, zooxanthellae from clams exposed to $P$ had significantly higher $\mathrm{N}$ depletion rates than zooxanthellae from control clams (Fig. 2). This indicates that the resident zooxanthellae had access to some internal sources of $P$ that increased their demand for $\mathrm{N}$, albeit an insufficient demand to significantly enhance their growth or influence their $N: P$ ratio. Indeed, it has been shown that plant cells require small amounts of inorganic $\mathrm{P}$ in order to use inorganic N (Ryther \& Dunstan 1971). All these trends suggest greater access of zooxanthellae in situ to increased $\mathrm{N}$ concentrations in sea water, than to $P$ (Belda et al. 1993b)
One surprising trend observed in this study was the much higher ammonium levels in the haemolymph of Tridacna maxima (Table 2) than those which have been previously observed in T. gigas (Fitt et al. 1995). These high levels were in apparent conflict with the high ammonium uptake rates in control clams (Fig. 2), and suggest that ammonium concentration in the haemolymph is not the sole determinant of ammonium availability to the zooxanthellae, at least in $T$. maxima. Furthermore, any differences between treatments may have been potentially obscured by the significant variation due to the different micro-atolls. It is interesting that ammonia levels in the haemolymph after 3 mo of fertilisation were reduced by about $50 \%$ from that found after a month of nutrient exposure (Table 2). This is consistent with the decrease in the zooxanthellae's N:P ratios over time (Table 1 ).

The observed amino-acid composition of the haemolymph was unexpected since the gin:glu ratio was unaffected by an increase in ammonium levels in sea water and there was a drop in glu with $\mathrm{N}$ exposure (Fig. 4a). This is in direct contrast to the response observed in the haemolymph of Tridacna gigas, in which a dramatic and immediate increase in gln concentration was observed when clams were exposed to $20 \mu \mathrm{M}$ ammonium in sea water (Shepherd et al. 1998). Gln:glu is a biologically relevant indicator of $\mathrm{N}$ status relative to carbon availability for many microalgae (reviewed in Cook et al. 1997), and if ammonium was assimilated by the zooxanthellae, one would expect a rise in gln in the haemolymph, assuming that it is released by the algae. It may be that the intrinsically high ammonium concentrations in the haemolymph of $T$. maxima are unaffected by exposure to $\mathrm{N}$ enrichment, indicating that there is no need for metabolic adjustment following an increase in availability of ammonium to the clam. Alternatively, any increase in gln concentration could have been immediate and short lived, and therefore missed during sampling. Indeed, gln:glu is sensitive to changes in either $\mathrm{N}$ or $\mathrm{C}$ availability over very short time periods (min or $h$ ), and might be most applicable for monitoring short-term $\mathrm{N}$ sufficiency (see Cook et al. 1997).

Some pools of free amino acids in the zooxanthellae (met, tyr) increased with $N$ exposure of the clams (Fig. 4b). However, these amino acids are non-basic and may not be reliable indicators of $N$ sufficiency in zooxanthellae. Basic internal amino acid (BIAA. his, lys, orn, arg) pools function as nitrogen-rich storage compounds in zooxanthellae, free-living dinoflagellates, and other microalgae (reviewed in Cook et al 1997 ). It is possible that any potential effects of $\mathrm{N}$ treatment on most free-amino-acid pools in the zooxanthellae were obscured by the significant variation due to the different micro-atolls. Alternatively, the BIAA 
pools may not be responsive indicators of nitrogen sufficiency in clam zooxanthellae over the duration of the study.

\section{Bio-indicators of early eutrophication in reef waters}

The general agreement of the results of this field investigation and previous onshore studies (Belda et al. 1993b, Belda \& Yellowlees 1995), despite the fact that different species of clams were investigated in each case, is quite lucid. This has direct implications for tridacnids and, almost certainly, other symbiotic associations in their natural environment. Reef organisms symbiotic with zooxanthellae are adapted to the poor nutrient conditions of reef waters. Consequently, any chronic increase in nutrient levels substantially affects the symbiotic partners.

One month fertilisation of the micro-atolls did not produce significant changes in the host and symbiont parameters examined, although the symbiotic partners' N:P ratios and haemolymph nutrient levels already showed trends consistent with those observed later. Nevertheless, discernible effects of elevated nutrient concentrations on clams and their zooxanthellae were clearly evident after 3 mo and might have even been significant at an earlier stage in the fertilisation

In contrast, coral colonies of Pocillopora damicornis and Stylophora pistillata incubated during the first half of the ENCORE nutrient-enrichment phase $(10 \mu \mathrm{MN}$, $2 \mu \mathrm{M}$ P) did not show significant changes, results which the investigators attributed to the potential masking of treatment effects by season and coral parentage (Hoegh-Guldberg et al. 1997). Only during the latter intensified half of the nutrient-enrichment phase were these corals observed to have reduced calcification rates with $\mathrm{P}$ exposure and increased skeletal extension rates with $\mathrm{N}$ exposure, even though the differences were insignificant (cf. Belda et al. 1993a). Similarly, it took 6 mo of exposure of Acropora palifera colonies to $20 \mu \mathrm{M} \mathrm{N}$ and/or $4 \mu \mathrm{M}$ P before significant increases could be discrened in zooxanthellae pigment concentrations and densities with $\mathrm{N}$ and $\mathrm{N}+\mathrm{P}$, respectively, and an increase or decrease in skeletal growth rates with $\mathrm{P}$ or $\mathrm{N}$, respectively (Steven \& Broadbent 1997). Other ENCORE studies showed that nutrient enrichment did not affect the C:N:P ratios of the zooxanthellate soft coral Sarcophyton sp. (Tentori et al. 1997), but reduced the larval settlement rates of the reef coral A. longicyathus during the 5 d larval settlement period (Ward \& Harrison 1997).

That some zooxanthellate corals did not manifest significant results until much later and at higher nutrient concentrations demonstrates that they may have less sensitivity to changes in ambient nutrient levels in sea water compared to giant clams and their algal symbionts. Although some in situ effects on giant clams were more subtle than those previously observed in the laboratory, they are still important given the short exposure time to the minimal nutrient loading in the field, where biological competition and local tidal conditions affect nutrient availability.

The present findings indicate that giant clams and their algal symbionts are able to compete well with other zooxantheilate reef organisms for available nutrients, and that they have a potential use as sub-lethal indicators of eutrophication in reef waters. The clam zooxanthellae's nutrient status is particularly relevant as an indicator of reef eutrophication, specifically with respect to $N$ enrichment. Compared to direct measurement of temporally and spatially variable nutrient levels in the water column, the zooxanthellae's nutrient status integrates short-term signals of nutrient loading, and allows assessment of long-term changes in nutrient supply with repeated sampling (Cook et al. 1997). Protocols for the non- destructive sampling of the mantle and adductor muscle (Benzie et al. 1993), growing shell edges (see Belda et al. 1993a), and haemolymph (Rees et al. 1993) are available. Although tridacnid populations are declining and large species are listed as endangered (Lucas 1994), the small species like Tridacna crocea and $T$ maxima still occur in reasonable abundance within their natural geographic range (Juinio et al. 1989, Lucas 1994). Furthermore, there is scope for use of cultured clams as test organisms for monitoring purposes in reef waters

It is interesting to note that there was a lack of response of some reef communities to nutrient enrichment in the ENCORE experiment. For instance, primary production of the epilithic algal community on dead coral blocks (Larkum \& Koop 1997), rates of surface erosion due to grazing or endolithic colonisation of micro- and macroborers of exposed experimental substrates (Kiene 1997), and ammonium affinities of microphytes in sediments (Bishop \& Duckworth 1997) were all unaffected by fertilisation. It has been suggested that nutrient conditions at the surface of the One Tree Island microatolls are already sufficient to support these communities (Kiene 1997, Larkum \& Koop 1997). These studies demonstrate that not all communities in oligotrophic reef waters, particularly non-symbiotic associations or noncalcifying organisms, are necessarily nutrient-limited.

In conclusion, this study underscores the limiting roles of both $\mathrm{N}$ and $\mathrm{P}$ in the giant clam-zooxanthellae symbiosis. It further provides valuable insights into organism-level responses of a symbiotic association to nutrient enrichment in reef waters, demonstrating the potential use of giant clams and their zooxanthellae as bio-indicators of the early onset of eutrophication in reef waters. 
Acknowledgements. Financial support came from the ACIAR-AIDAB fellowship grant to C.A.B.-B. and from a CiBRMPA grant to D.Y GBRMPA gave permission (ENCORE Permit No. G92/382) to use part of a natural population of Tridacna maxima on One Tree Island Reef, and Ove HoeghGuldberg collected and placed the clams in the experimental micro-atolls. Thanks are also due to Brett Baillie, Mabs Johnston, Alwyn Rees, Tina Tentori, Dorthe Siggaard, and Dave Hawkings for their technical assistance; and to the staff of the One Tree Island Research Station, Greg and Peta Carter, for their valuable help. Three anonymous reviewers made valuable suggestions in drafting the final manuscript. This is contribution no. 282 from the University of the Philippines Marine Science Institute

\section{LITERATURE CITED}

Allen SE (1974) Chemical analysis of ecological materials Blackwell, Oxford

Ambariyanto, Hoegh-Guldberg $O$ (1996) Nutrient enrichment and the ultrastructure of zooxanthellae from the giant clam Tridacna maxima. Mar Biol 25:359-363

Analytical Software ${ }^{\widetilde{0}}$ (1985) Statistix 3.0: an interactive statistical analysis program for microcomputers. Analytical Software, St. Paul, MN

Atkinson MJ, Smith SV (1983) C:N:P ratios of benthic marine plants. Limnol. Oceanogr. 28:568-574

Belda CA, Cuff C, Yellowlees D (1993a) Modification of shell formation in the giant clam Tridacna gigas at elevated. nutrient levels in sea water. Mar Biol 117:251-257

Belda CA, Lucas JS, Yellowlees D (1993b) Nutrient limitation in the giant clam-zooxanthellae symbiosis: effects of nutrient supplements on growth of the symbiotic partners Mar Biol 117:655-664

Belda CA, Yellowlees D (1995) Phosphate acquisition in the giant clam-zooxanthellae symbiosis. Mar Biol 124 $261-266$

Benzie JAH, Wllliams ST, Macaranas JM (1993). Allozyme electrophoretic methods for analysing genetic variation in giant clams (Tridacnidae). Tech Rep No 23, Australian Centre for International Agricultural Research, Canberra

Bishop JW, Duckworth OW (1997) Ammonium affinity of sediments in ENCORE microatolls. Proc 8th Int Coral Reef Symp 1:877-880

Cook CB, Mulle--Parker G, Ferrier MD (1997) An assessment of indices of nutrient sufficiency in symbiotic dinoflagellates. Proc 8th Int Coral Reef Symp 1:903-908

Deane EM, O'Brien RW (1980) Composition of the haemolymph of Tridacna maxima (Mollusca: Bivalvia). Comp Biochem Physiol 66A:338-341

Fitt WK, Heslinga GA, Watson TC (1993) Utilisation of dissolved inorganic nutrients in growth and mariculture of the tridacnid clam Tridacna derasa. Aquaculture 109: $27-38$

Fitt WK, Rees TAV, Yellowlees D (1995) Relationship between $\mathrm{pH}$ and the availability of dissolved inorganic nitrogen in the zooxanthellae-giant clam symbiosis. Limnol Oceanogr 40:976-982

Hastie L, Watson TC, Isamu T, Heslinga GA (1992) Effect of nutrient ennchment on Tridacna derasa seed: dissolved inorganic nitrogen increases growth rate. Aquaculture 106:41-49

Hawkins AJS, Klumpp DW (1995) Nutrition of the giant clam Tridacna gigas (L.). II. Relative contributions of filter-feeding and ammonium-nitrogen acquired and recycled by symbiotic alga towards total nitrogen requirements for tis- sue growth and metabolism. I Exp Mar Biol Ecol 190 $263-290$

Hoegh-Guldberg $O$ (1994) The population dynamics of symbiotic zooxanthellae in the coral pocillopora damiconis exposed to elevated ammonia. Pac Sci 48(3):263-272

Hoegh-Guldberg O, Hinde R, Muscatine L (1986) Studies on a nudibranch that contains zooxanthellae. II. Contribution of zooxanthellae to animal respiration (CZAR) in Pteraeolidia ianthina with high and low densities of zooxanthellae. Proc R Soc Lond Ser B Biol Sci 228:511-521

Hoegh-Guldberg O, Takabayashi M, Moreno G (1997) The impact of long-term nutrient enrichment on coral calcification and growth. Proc 8th Int Coral Reef Symp 1:861-866

Jokiel PL, Dubinsky, Z, Stambler N (1994) Results of the 1991 United States - Israel workshop, 'Nutrient limitation in the symbiotic association between zooxanthellae and reefbuilding corals'. Pac Sci 48(3):215-218

Juinio MAR, Menez LAB, Villanoy CV, Gomez ED (1989) Status of giant clam resources in the Philippines. J Molluscan Stud 55:431-440.

Kuene WE (1997) Enriched nutrients and their impact on bioerosion: results from ENCORE. Proc 8th Int Coral Reef Symp 1:897-902

Kinsey DW (1988) Coral reef system response to some natural and anthropogenic stresses. Galaxea 7:113-128

Kinsey DW, Davies PJ (1979) Effects of elevated nitrogen and phosphorus on coral reef growth. Limnol Oceanogr 24: 935-940

Kinsey DW, Domm A (1974) Effects of fertilisation on a coral reef environment-primary production studies. Proc 2 nd Int Coral Reef Symp 1:49-66

Klumpp DW, Bayne BL, Hawkins AJS (1992) Nutrition of the giant clam Tridacna gigas (L.) I. Contributions of filter feeding and photosynthesis to respiration and growth. J Exp Mar Biol Ecol 155:105-122

Koroleff F (1983) Simultaneous oxidation of nitrogen and phosphorus compounds by persulphate. In: Grasshoff K, Ehrhardt $M$, Kremling K (eds) Methods of seawater analysis, 2nd erin. Verlag Cheme GmbH, Weinheim, p 168-169

Larkum AWD, Koop K (1997) ENCORE, algal productivity and possible paradigm shifts. Proc 8th Int Coral Reef Symp $1: 881-884$

Larkum AWD Steven ADL (1994) ENCORE: the effect of nutrient enrichment on coral reefs. 1. Experimental design and research programme. Mar Pollut Bull 29:112-120

Liddicoat MI, Tibbits S, Butler EI (1975) The determination of ammonia in seawater. Limnol Oceanogr 20:131-132

Lucas JS (1994) The biology, exploitation, and mariculture of giant clams (Tridacnidae). Rev Fisheries Sci. 2(3):181-223

Magne C, Larher F (1992) High sugar content extracts interfere with colorimetric cetermination of amino acids and free proline. Anal Biochem 200:115-118

McAuley PJ (1994) Amino acid content of zooxanthellae freshly isolated from Pocillopora damicornis. Pac Sci 48(3): 247-253

Muller-Parker G, Cook CB, D'Elia CF (1994a) Elemental composition of the coral. Pocillopora damicornis exposed to elevated seawater ammonium. Pac Sci 48(3):234-246

Muller-Parker G, McCloskey LR, Hoegh-Guldberg O, McAuley PJ (1994b) Effect of ammonium enrichment on anumal and alral biomass of the coral pocillopora damicornis. Pár Sci 48(3):273-283

Rees TA, Fitt WK, Baillie B, Yellowlees D (1993) A method for temporal measurement of haemolymph composition in the giant clam symbiosis and its application to glucose and glycerol levels during a diel cycle. Limnol Oceanogr 38(1): 213-217 
Ryther JH, Dunstan WM (1971) Nitrogen, phosphorus, and eutrophication in the coastal marine environment. Science 171:1008-1013

Sheppard D, Leggat W, Rees TAV, Yellowlees D (1998) Ammonjum, but not nitrate, stimulates an increase in glutamine concentration in the haemolymph of Tridacna gigas. Mar Biol (in press)

Steven ADL, Broadbent AD (1997) Growth and metabolic responses of Acropora palifera to long term nutrient enrichment. Proc 8th Int Coral Reef Symp 1:867-872

Strickland JDH, Parsons TR (1972) A practical handbook of seawater analysis, 2nd edn. Bull Fish Res Bd Can 167

Tentori E, Coll JC. Fleury B (1997) ENCORE; effects of elevated nutrients on the C:N:P ratios of Sarcophyton $\mathrm{sp}$. (Alcyonacea). Proc 8th Int Coral Reef Symp 1:885-890

Underwood AJ (1981) Techniques of analysis of variance in experimental marine biology and ecology. Oceanogr Mar Biol Annu Rev 19:513-605

Editorial responsibility: David Klumpp (Contributing Editor), Townsville, Queensland, Australia
Ward S, Harrison FL (1997) The effects of elevated nutrient levels on settlement of coral larvae during the ENCORE experiment, GBR, Australia. Proc 8th Int Coral Reef Symp $1: 891-896$

Wilkerson FP, Kobayashi D, Muscatine L (1988) Mitotic index and size of symbiotic algae in Carribbean reef corals. Coral Reefs 7:29-36

Wilkerson FP. Trench RK (1986) Uptake of dissolved inorganic nitrogen by the symbiotic clam Tridacna gigas and the coral Acropora sp. Mar Biol 93:237-246

Yellowlees D. Rees TAV, Fitt WK (1994) Effect of ammoniumsupplemented seawater on glutamine synthetase and glutamate dehydrogenase activities in host tissue and zooxanthellae of Pocillopora damicornis and on ammonium uptake rates of the zooxanthellae. Pac Sci 48(3): $291-295$

Zar JJ (1984) Biostatistical analysis, 2nd edn. Prentice-Hall, Englewood Cliffs, NJ

Submitted: August 16, 1997; Accepted: April 16, 1998 Proofs received from author(s): August 3, 1998 